\title{
Tar Spot of Maize: Current knowledge of genetic interactions and future research prospects to improve disease resistance
}

\author{
Matthew Helm ${ }^{1}$ \\ ${ }^{1}$ Affiliation not available
}

March 7, 2022

Matthew Helm, ${ }^{1 *}$ Raksha Singh, ${ }^{1}$ Stephen B. Goodwin, ${ }^{1}$ Denise Caldwell, ${ }^{2}$ and Anjali S. Iyer-Pascuzzi ${ }^{2}$

${ }^{1}$ Crop Production and Pest Control Research Unit, U.S. Department of Agriculture-Agricultural Research Service (USDA-ARS), West Lafayette, IN 47907-2054, U.S.A.

${ }^{2}$ Department of Botany and Plant Pathology, Purdue University, West Lafayette, IN 47907-2054, U.S.A.

* Corresponding author : M. Helm; Email: Matthew.Helm@usda.gov

Funding: This work was supported by the United States Department of Agriculture, Agriculture Research Service (USDA-ARS) research project 5020-21220-019-00D.

\section{Abstract}

The emergence and spread of crop plant pathogens pose a significant risk to global food and nutritional security. Of particular concern are those fungal pathogens that can significantly reduce yields of staple crop plants such as maize (Zea mays subsp. mays). One such plant pathogen is Phyllachora maydis Maubl $(P$. maydis ), which causes tar spot disease on maize. Though it was only recently identified within the United States, P. maydis is now considered one of the most economically important foliar diseases of maize and has since spread to most maize production areas within the United States and Canada, resulting in substantial yield losses. In this mini-review, we aim to summarize recent advancements in our understanding of the genetic interactions between maize and $P$. maydis whilst also highlighting future research prospects for developing genetic-based resistances.

Keywords: Maize, Phyllachora maydis, tar spot, disease resistance

\section{Introduction}

Maize (Zea mays subsp. mays) is one of the most widely cultivated cereal grains and serves as a significant source of calories for human and animal consumption. Though there are a multitude of threats to global maize production, substantial yield losses caused by diseases significantly challenge our ability to achieve global food and nutritional security sustainably and impose significant financial constraints to growers (Savary et al., 2019). Of particular concern are fungal pathogens capable of causing global pandemics and significantly reducing maize yields (Savary et al., 2019). One such fungal pathogen is the ascomycete Phyllachora maydis Maubl (P. maydis ), a foliar pathogen of maize that causes tar spot disease (Ruhl et al., 2016; Figure 1A-B). First documented in Mexico in 1904, P. maydisis endemic to Central and South America where it has the potential to significantly reduce grain yields, especially under favorable environmental conditions (Maublanc 1904; Valle-Torres et al., 2020). Though P. maydis is often associated with tropical maize production areas, it emerged in Illinois and Indiana during 2015 and has since spread to several other maize-growing areas 
within the United States and Canada (Rocco da Silva et al., 2021; Ruhl et al., 2016; Valle-Torres et al., 2020). Such rapid emergence and spread of $P$. maydis across varying geographical climates strongly suggests commercial maize hybrids in the United States are susceptible to this fungal pathogen. To this end, Telenko et al. (2019) evaluated a subset of commercially grown maize hybrids for their responses to $P$. maydis and showed that all hybrids tested were susceptible. Notably, a severe tar spot epidemic within the United States in 2018 resulted in an estimated $~ \$ 840$ million USD economic loss, demonstrating $P$. maydis is capable of imposing severe financial constraints to growers (Crop Protection Network, 2021). The current lack of durable, genetic-based resistance coupled with its potential to significantly reduce maize yields makes $P$. maydis one of the most economically important foliar diseases of maize (Mueller et al., 2020). Hence, future research should, in part, investigate the genetic mechanisms underlying maize- $P$. maydis interactions to improve tar spot resistance.

\section{Population screens and linkage mapping have contributed to our understanding of the maize- P. maydis pathosystem}

Our general knowledge regarding $P$. maydis resistance in temperate-derived maize remains limited given its recent emergence within the continental United States and Canada. However, sources of resistance to P. maydis have been identified in diverse maize germplasm collections. Mahuku et al. (2016) and Cao et al. (2017) performed Genome-Wide Association Studies (GWAS) on diverse mapping populations and identified a large-effect Quantitative Trait Locus (QTL) on chromosome 8 (bin 8.03), referred to as qRtsc81 . Fine-mapping of this locus revealed two candidate genes GRMZM2G063511 and GRMZM2G073884, encoding an integral membrane protein and a putative leucine-rich repeat receptor-like protein, respectively, as likely having a functional role in P. maydis recognition (Ren et al., 2022). It is worth noting that integral membrane proteins and leucine-rich repeat receptor-like proteins are known to have a functional role in Surface Receptor-Mediated Immunity (SRMI) against several plant pathogens (Ding et al., 2021; Yadeta et al., 2013). It remains unclear, however, what pathogen-derived proteins are recognized by these host proteins and how their activation induces resistance to $P$. maydis .

To identify new allelic diversity against P. maydis, Lipps et al. (2022) screened several maize accessions developed by the Germplasm Enhancement of Maize (GEM) project. Though no line showed complete resistance, two accessions, GEMS-0066 and GEMS-0226, consistently displayed partial resistance to P. maydis across multiple geographical locations. These lines may thus serve as important sources of new resistance specificities (Lipps et al., 2022). Furthermore, 200 GEM accessions and a subset of 600 inbred lines from the Wisconsin Diversity Panel-942 (WiDiv-942) were evaluated from their responses to $P$. maydis (A. Thompson, personal communication ). GWAS analysis revealed more than 100 Single Nucleotide Polymorphisms (SNPs) were associated with $P$. maydis tolerance (A. Thompson, personal communication ). Intriguingly, several of the identified SNPs were linked to defense-related genes and may thus be important for $P$. maydis resistance (A. Thompson, personal communication ).

The maize Nested Association Mapping (NAM) recombinant inbred lines (RILs) representing global maize diversity were derived from 26 inbred founder lines and are a valuable genetic resource that may contain additional allelic diversity against $P$. maydis (Gage et al., 2020). Indeed, the 26 inbred NAM founders were recently evaluated for their responses to $P$. maydis with the goal of identifying inbreds that are either resistant or susceptible to this fungal pathogen (R. Singh, personal communication). Though all inbred lines evaluated were susceptible, there were significant variations in their responses (Figure 1C). Nine inbred lines were scored as tolerant without complete resistance, six as moderately tolerant, two moderately susceptible, and the remaining eight were susceptible (R. Singh, personal communication ). Intriguingly, most of the CIMMYT-derived maize lines (CMLs) were evaluated as tolerant or moderately tolerant. In contrast, the North American-derived lines, including B73, displayed varying levels of susceptibility but most inbreds were susceptible (R. Singh,personal communication). Variations in susceptibility of the 26 founder lines to $P$. maydis could help guide the selection of appropriate NAM mapping populations for future genetic studies. Future research efforts should thus focus on fine mapping the genetic loci responsible for $P$. maydis resistance via GWAS and/or SNP linkage map analysis. Collectively, these studies demonstrate that diverse maize 
germplasm collections harbor genetic-based disease resistances to $P$. maydis and have been instrumental in our initial understanding of the genetic architecture underlying resistance to P. maydis .

Research prospects to improve disease resistance to P. maydis

The data thus far suggest $P$. maydis can cause significant yield losses in maize and should thus be considered a serious concern for maize growers. We, therefore, would like to propose high-priority research avenues likely to advance our fundamental understanding of the maize- $P$. maydis pathosystem.

\section{Screen additional maize germplasm to identify new sources of resistance to $P$. maydis}

Immediate efforts should focus, in part, on evaluating additional maize germplasm collections for resistance to $P$. maydis . In addition to screening the aforementioned natural germplasm collections, artificially generated germplasms also may serve as a useful resource for identifying new sources of resistance to $P$. maydis (Figure 2A). Ethyl methanesulfonate (EMS)-mediated mutagenesis of pollen grains is often used to generate mutagenic populations of maize that can then be subsequently used to screen for specific phenotypes (Candela and Hake, 2008). For example, Marla et al. (2018) used an EMS-mutagenized population of maize to generate and functionally characterize novel mutant alleles of the $H m 1$ resistance gene. It is thus likely a similar chemical mutagenesis-based strategy could be deployed to identify new sources of genetic resistance against multiple $P$. maydis isolates. One advantage of screening an EMS-mutagenized population is the likelihood of identifying susceptibility genes, which are host proteins required by the pathogen to facilitate infection (Garcia-Ruiz et al., 2021; Langner et al., 2018). For this reason, inactivation of host susceptibility genes often compromises pathogen infection, thereby conferring resistance (Garcia-Ruiz et al., 2021; Langner et al., 2018). Therefore, screening an EMS-mutagenized population of maize for loss of susceptibility to $P$. maydis may be an attractive approach for identifying new resistance loci.

\section{Investigate the infection strategy of $\boldsymbol{P}$. maydis using high-resolution microscopy}

In parallel to screening natural and artificial maize populations for new resistance alleles, additional studies should also aim to investigate the infection strategy used by $P$. maydis at the individual plant scale (Figure 2B). Currently, P. maydis is presumed an obligate biotrophic fungal pathogen as it likely requires photosynthetically active tissue for survival and is unable to be cultured in the laboratory (Rocco da Silva et al., 2021; Telenko et al., 2020). However, P. maydis has also been shown to overwinter on maize debris in the United States (Kleczewski et al., 2019b; Groves et al., 2020), suggesting it can survive as a saprophyte and may exhibit a bi-phasic lifestyle. Hence, P. maydis may be considered a hemibiotroph. Furthermore, our current understanding regarding the mechanisms underlying initial host infection and systemic spread is limited but is urgently needed to understand host immune mechanisms. High-resolution microscopy, in which the host and associated microbe are clearly observed at cell-type resolution (Caldwell et al., 2019), offers the potential to help elucidate the pathogen lifestyle and infection strategy of $P$. maydis within the host plant. For example, confocal microscopy revealed that Fusarium oxysporum f. sp.lycopersici first infects tomato root hairs and colonizes junctions between root epidermal cells (Lagopodi et al. 2002). Confocal microscopy also revealed differences in the root infection strategy between highly and weakly virulent strains of Fusarium oxysporumf. sp. phaseoli in susceptible common bean (Nino-Sanchez et al. 2015). The highly virulent strain reached the root xylem faster than the weakly virulent strain, which predominantly colonized the root cortex (Nino-Sanchez et al. 2015). Microscopy has also revealed differences inFusarium colonization between resistant and susceptible cultivars in several species, including banana (Chen et al. 2019) and chickpea (Jimenez-Fernandez et al. 2013). Using such microscopy methods in plants with differing responses to $P$. maydis will help us elucidate whether this fungal pathogen is biotrophic or hemibiotrophic as well as shed light on the underlying resistance mechanisms in maize.

\section{$P$. maydis genomic surveillance and isolate profiling using a field pathogenomics strategy}

A detailed understanding of the current genetic diversity and population structure of $P$. maydis populations is limited. Such information is critical for monitoring $P$. maydis outbreaks and for the emergence of new P. maydis populations with potential resistance to fungicides. To this end, Broders et al. (2021) assessed 
the sequence diversity of $P$. maydis collected from 186 single stroma derived from 16 hosts in an effort to initially understand the genetic diversity within $P$. maydis populations. Intriguingly, sequencing of the internal transcribed spacer (ITS) region from these samples revealed that there are likely three genetically distinct groups of P. maydis in the United States capable of infecting maize (Broders et al., 2021). However, the phylogenetic analysis performed was based only on sequencing of the ITS region and historical representatives from herbaria and may not be representative of current populations. Alternatively, whole transcriptome sequencing of $P$. maydis -infected tissue collected directly from the field offers a more thorough and detailed understanding of host-pathogen interactions (Figure 2C). This approach, termed field pathogenomics, presents a detailed analysis of the population structure and genetic diversity of $P$. maydis as well as informative gene expression data for both the host and pathogen. Field pathogenomics has been used to identify new lineages of wheat yellow rust populations in the United Kingdom (Hubbard et al., 2015) and the origins of wheat blast in Bangladesh (Islam et al., 2016; Kamoun et al., 2019). For these reasons, the field pathogenomics strategy may be an attractive approach to actively monitor $P$. maydis populations for the emergence of novel isolates.

\section{Characterize $P$. maydis virulence (effector) proteins and their host targets in maize}

Virulence proteins translocated by fungal pathogens often have a functional role in promoting plant disease either by suppressing or activating host immune responses and, therefore, can serve as important resources for introducing novel host resistance specificities (Figueroa et al., 2021). Though P. maydis is predicted to secrete effector proteins (Telenko et al., 2020), our general understanding of how $P$. maydis utilizes its effector repertoire for virulence as well as their host targets in maize remain unknown. Such studies are complicated by the observation that $P$. maydis is genetically intractable and culturing of this pathogen has not been successful (Rocco da Silva et al., 2021; Telenko et al., 2020). Hence, genetic manipulation of the fungal pathogen is not yet possible. Furthermore, controlled inoculation protocols using P. maydis have yet to be developed, thus greenhouse-based disease assays aimed at evaluating host responses to $P$. maydis cannot be performed. Despite these limitations, screening the effector repertoire of $P$. maydis can be performed through the use of heterologous expression systems in non-host plants such as Arabidopsis thaliana and Nicotiana benthamiana (Figueroa et al., 2021; Lorrain et al., 2018). This strategy has been effective at revealing the specific plant cell compartments targeted by effectors from other obligate biotrophic fungi as well as their host protein interactors (Figueroa et al., 2021; Lorrain et al., 2018). Future work should thus aim to exploit the use of heterologous plant systems to investigate the subcellular compartments targeted by $P$. maydis effector proteins as well as identify their host targets in maize (Figure 2D). Such information is likely to advance our understanding of the molecular interactions between $P$. maydisand host as well as provide initial insight into the pathogenicity mechanisms used by P. maydis to promote disease.

\section{Concluding remarks}

The rapid emergence and spread of $P$. maydis within the United States poses a significant threat to maize production. Most commercial U.S. maize hybrids are susceptible to $P$. maydis, and naturally occurring resistance genes have yet to be identified and functionally characterized. For these reasons, we aspire to synergize collaborations among multidisciplinary research experts in an attempt to: 1) evaluate additional germplasm collections for $P$. maydis resistance; 2) determine the lifestyle and host infection strategy of this fungal pathogen; 3) assess its population diversity; and 4) characterize the P. maydis effector repertoire and identify their host targets in maize (Figure 2). Such multidisciplinary research collaborations will likely accelerate the development and deployment of maize hybrids with genetic-based disease resistance to $P$. maydis .

\section{Author Contributions}

We sincerely apologize to colleagues whose works we were not able to cite due to space limitations. MH conceived this minireview. MH produced the first draft, and all authors critically revised the manuscript. All authors approved the final version of the manuscript.

\section{Funding}


This research was funded, in part, by the United States Department of Agriculture, Agriculture Research Service (USDA-ARS) research project 5020-21220-019-00D. The funding body had no role in designing the experiments, collecting the data, or writing the manuscript. Mention of trade names or commercial products in this publication is solely for the purpose of providing specific information and does not imply recommendation or endorsements by the United States Department of Agriculture. USDA is an equal opportunity provider and employer.

\section{Acknowledgements}

We thank Dr. Morgan E. Carter (University of Arizona) for critical reading of this manuscript and helpful comments. The authors also thank Dr. Gurmukh Johal (Purdue University) for providing photographs of $P$. maydis -infected leaf tissue.

\section{Literature Cited}

Broders, K., Iriarte, G., Bergstrom, G., et al. 2021. Phyllachora species infecting maize and other grass species throughout the Americas represents a complex of closely related species which vary in their host and geographic range. Preprint on Authorea. DOI: 10.22541/au.163978585.51585137/v1

Caldwell, D., and Iyer-Pascuzzi, A.S. 2019. A scanning electron microscopy technique for viewing plantmicrobe interactions at tissue and cell-type resolution. Phytopathology 109: 1302-1311.

Candela, H., and Hake, S. 2008. The art and design of genetic screens: maize. Nat Rev Genet. 9: 192-203. doi: $10.1038 / \mathrm{nrg} 2291$.

Cao, S., A. Loladze, Y. Yuan, Y. Wu, A. Zhang, J. Chen, G. Huestis, J. Cao, V. Chaikam, M. Olsen, B. M. Prasanna, F. San Vicente, and X. Zhang. 2017. Genome-Wide Analysis of tar spot complex resistance in maize using genotyping-by- sequencing SNPs and whole-genome prediction. The Plant Genome 10. doi: 10.3835/plantgenome2016.10.0099.

Chen, A., Sun, J., Matthews, A., Armas-Egas, L., Chen, N., Hamill, S., Mintoff, S., Tran-Nguyen, L.T.T., Batley, J., Aitken, E.A.B. 2019. Assessing Variations in Host Resistance to Fusarium oxysporum f sp. cubense Race 4 in Musa Species, With a Focus on the Subtropical Race 4. Front Microbiol. 10:1062. doi: 10.3389/fmicb.2019.01062.

Crop Protection Network (2021). How Tar Spot of Corn Impacted Hybrid Yields During the 2018 Midwest Epidemic. Available online at: https://cropprotectionnetwork.org/resources/publications/how-tar-spot-ofcorn-impacted-hybrid-yields-during-the-2018-midwest-epidemic

Ding, P., Sakai, T., Shrestha, R.K., Perez, N.M., Guo, W., Ngou, B.P.M., He, S., Liu, C., Feng, X., Zhang, R., Vandepoele, K., MacLean, D., Jones, J.D.G. 2021. Chromatin accessibility landscapes activated by cell-surface and intracellular immune receptors. J. Exp. Bot. 72: 7927-7941. https://doi.org/10.1093/jxb/erab373

Figueroa, M., Ortiz, D., and Henningsen, E.C. 2021. Tactics of host manipulation by intracellular effectors from plant pathogenic fungi. Curr. Opin. Plant Biol. 62: 102054. https://doi.org/10.1016/j.pbi.2021.102054

Gage, J.L., Monier, B., Giri, A., Buckler, E.S. 2020. Ten Years of the Maize Nested Association Mapping Population: Impact, Limitations, and Future Directions. Plant Cell 32: 2083-2093. https://doi.org/10.1105/tpc.19.00951

Garcia-Ruiz, H., Szurek, B., Van den Ackerveken, G. 2021. Stop helping pathogens: engineering plant susceptibility genes for durable resistance. Curr Opin Biotechnol 70: 187195. https://doi.org/10.1016/j.copbio.2021.05.005

Groves, C. L., Kleczewski, N. M., Telenko, D. E. P., Chilvers, M. I., and Smith, D. L. 2020. Phyllachora maydis ascospore release and germination from overwintered corn residue. Plant Health Prog. 21: 26-30. 
Hubbard, A., Lewis, C.M., Yoshida, K. et al. 2015. Field pathogenomics reveals the emergence of a diverse wheat yellow rust population. Genome Biol. 16: 23. https://doi.org/10.1186/s13059-015-0590-8.

Islam, M.T., Croll, D., Gladieux, P. et al. 2016. Emergence of wheat blast in Bangladesh was caused by a South American lineage ofMagnaporthe oryzae. BMC Biol. 14: 84. https://doi.org/10.1186/s12915-0160309-7

Jiménez-Fernández, D., Landa, B.B., Kang, S., Jiménez-Díaz, R.M., Navas-Cortés, J.A. 2013. Quantitative and microscopic assessment of compatible and incompatible interactions between chickpea cultivars and Fusarium oxysporum f. sp. ciceris races. PLoS One. 8:e61360. doi: 10.1371/journal.pone.0061360.

Kamoun, S., Talbot, N.J., Islam, M.T. 2019. Plant health emergencies demand open science: Tackling a cereal killer on the run. PLoS Biol 17(6): e3000302. https://doi.org/10.1371/journal.pbio.3000302

Kleczewski, N. M., Donnelly, J., and Higgins, R. 2019. Phyllachora maydis , causal agent of tar spot on corn, can overwinter in northern Illinois. Plant Health Prog. 20:178. doi:10.1094/PHP-04-19-0030-BR.

Lagopodi, A.L., Ram, A.F., Lamers, G.E., Punt, P.J., Van den Hondel, C.A., Lugtenberg, B.J., Bloemberg, G.V. 2002 Novel aspects of tomato root colonization and infection by Fusarium oxysporum f. sp. radicislycopersici revealed by confocal laser scanning microscopic analysis using the green fluorescent protein as a marker. Mol Plant Microbe Interact. 15:172-179. doi: 10.1094/MPMI.2002.15.2.172.

Langner, T., Kamoun, S., and Belhaj, K. 2018. CRISPR Crops: Plant Genome Editing Toward Disease Resistance. Annu. Rev. Phytopathol. 56: 479-512. https://doi.org/10.1146/annurev-phyto-080417-050158

Lipps, S., Smith, D., Telenko, D., Paul, P., Kleczewski, N., \& Jamann, T. 2022. Identification of resistance for Phyllachora maydis of maize in exotic-derived germplasm. Crop Sci. 1-8. https://doi.org/10.1002/csc2.20709

Lorrain, C., Petre, B., Duplessis, S. 2018. Show me the way: rust effector targets in heterologous plant systems. Curr Opin Microbiol. 46:19-25. doi: 10.1016/j.mib.2018.01.016.

Mahuku, G., Chen, J., Shrestha, R., Narro, L. A., Osorio-Guerrero, K. V., Arcos A. L., and Xu, Y. 2016. Combined linkage and association mapping identifies a major QTL ( $q$ Rtsc8-1), conferring tar spot complex resistance in maize. Theor. Appl. Genet. 129:1217-1229. doi 10.1007/s00122-016-2698-y.

Marla, S.R., Chu, K., Chintamanani, S., Multani, D.S., Klempien, A., DeLeon, A., Kim, B.S., Dunkle, L.D., Dilkes, B.P., Johal, G.S. 2018. Adult plant resistance in maize to northern leaf spot is a feature of partial loss-of-function alleles of Hm1. PLoS Pathogens 14:e1007356. doi: 10.1371/journal.ppat.1007356.

Maublanc, A. 1904. Especes Nouvelles de champignons inferieurs. Bull. Soc. Mycol. Fr. 20:72-74.

Mueller, D. S., Wise, K. A., Sisson, A. J., Allen, T. W., Bergstrom, G. C., Bissonnette, K. M., Bradley, C. A., Byamukama, E., Chilvers, M. I., Collins, A. A., Esker, P. D., Faske, T. R., Friskop, A. J., Hagan, A. K., Heiniger, R. W., Hollier, C. A., Isakeit, T., Jackson-Ziems, T. A., Jardine, D. J., Kelly, H. M., Kleczewski, N. M., Koehler, A. M., Koenning, S. R., Malvick, D. K., Mehl, H. L., Meyer, R. F., Paul, P. A., Peltier, A. J., Price, P. P., Robertson, A. E., Roth, G. W., Sikora, E. J., Smith, D. L., Tande, C. A., Telenko, D. E. P., Tenuta, A. U., Thiessen, L. D., and Wiebold, W. J. 2020. Corn yield loss estimates due to diseases in the United States and Ontario, Canada, from 2016 to 2019. Plant Health Prog. 21: 238-247.

Niño-Sánchez, J., Tello, V., Casado-Del Castillo, V., Thon, M.R., Benito, E.P., Díaz-Mínguez, J.M. 2015. Gene expression patterns and dynamics of the colonization of common bean (Phaseolus vulgaris L.) by highly virulent and weakly virulent strains of Fusarium oxysporum. Front Microbiol . 6:234. doi:10.3389/fmicb.2015.00234

Ren, J., Wu, P., Huestis, G.M. et al. 2022. Identification and fine mapping of a major QTL (qRtsc8-1 ) conferring resistance to maize tar spot complex and validation of production markers in breeding lines. Theor. Appl. Genet. doi https://doi.org/10.1007/s00122-022-04053-8 
Rocco da Silva, C., Check, J., MacCready, J. S., Alakonya, A. E., Beiriger, R. L., Bissonnette, K. M., Collins, A., Cruz, C., Esker, P., Goodwin, S. B., Malvick, D., Mueller, D. S., Paul, P., Raid, R., Robertson, A. E., Roggenkamp, E., Ross, T. J., Singh, R., Smith, D. L., Tenuta, A., Chilvers, M. I., and Telenko, D. E. P. 2021. Recovery plan for tar spot of corn, caused by Phyllachora maydis . Plant Health Prog. 22: 596-616.

Ruhl, G., Romberg, M.K., Bissonnette, S., Plewa, D., Creswell, T., and Wise, K.A. 2016. First report of tar spot on corn caused by Phyllachora maydis in the United States. Plant Dis. 100: 1496

Savary, S., Willocquet, L., Pethybridge, S.J., Esker, P., McRoberts, N., and Nelson, A. 2019. The global burden of pathogens and pests on major food crops. Nat. Ecol. Evol. 3: 430-439.

Telenko, D. E. P., Chilvers, M. I., Kleczewski, N. M., Smith, D. L., Byrne, A. M., Devillez, P., Diallo, T., Higgins, R., Joos, D., Kohn, K., Lauer, J., Mueller, B., Singh, M. P., Widdicombe, W. D., and Williams, L. A. 2019. How tar spot of corn impacted hybrid yields during the 2018 Midwest epidemic. Crop Protection Network. doi: 10.31274/cpn- 20190729-002.

Telenko, D. E. P., Ross, T. J., Shim, S., Wang, Q., and Singh, R. 2020. Draft genome sequence resource for Phyllachora maydis - an obligate pathogen that causes tar spot of corn with recent economic impacts in the United States. Mol. Plant-Microbe Interact. 33: 884-887. https://doi.org/10.1094/MPMI-03-20-0075-A.

Valle-Torres, J., Ross, T. J., Plewa, D., Avellaneda, M. C., Check, J., Chilvers, M. I., Cruz, A. P., Dalla Lana, F., Groves, C., Gongora-Canul, C., Henriquez-Dole, L., Jamann, T., Kleczewski, N., Lipps, S., Malvick, D., McCoy, A. G., Mueller, D. S., Paul, P. A., Puerto, C., Schloemer, C., Raid, R. N., Robertson, A., Roggenkamp, E. M., Smith, D. L., Telenko, D. E. P., and Cruz, C. D. 2020. Tar Spot: an understudied disease threatening corn production in the Americas. Plant Dis. 104: 2541-2550.

Yadeta, K., Elmore, J.M., and Coaker, G. 2013. Advancements in the analysis of the Arabidopsis plasma membrane proteome. Front. Plant Sci. 4: 86.

\section{Figure Legends}

Figure 1. Phyllachora maydis disease symptoms on maize.A, Tar spot symptoms on foliage and husk leaves. Severe $P$. maydis infection often leads to premature senescence and blighting. B, Cross section of $P$. maydis -infected leaf tissue depicting a single perithecium with ascospores. C,Representative leaves from four maize accessions phenotyped as tolerant and susceptible to $P$. maydis .

Figure 2. Proposed research strategies to improve disease resistance to $\boldsymbol{P}$. maydis. A, Screening of additional maize germplasms may lead to the identification of new sources of resistance. B, High-resolution microscopy will help shed light on the pathogen lifestyle and infection strategy. C, Whole-transcriptome sequencing of $P$. maydis -infected tissue may be an effective approach to monitor pathogen populations for the emergence of novel isolates. D, Functionally characterizing the $P$. maydis effector repertoire and identifying their host targets in maize will help elucidate the virulence mechanisms that promote disease. Figure created withwww.BioRender.com.

Figure 1 
A

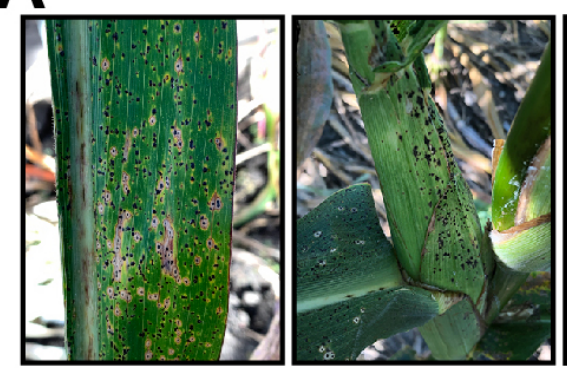

C

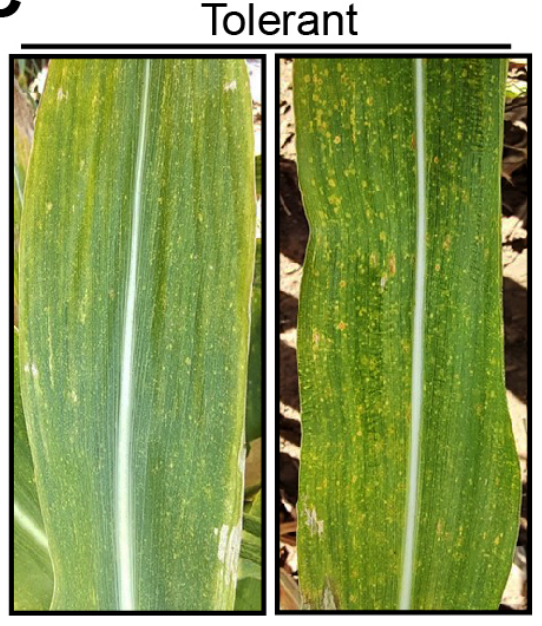

B
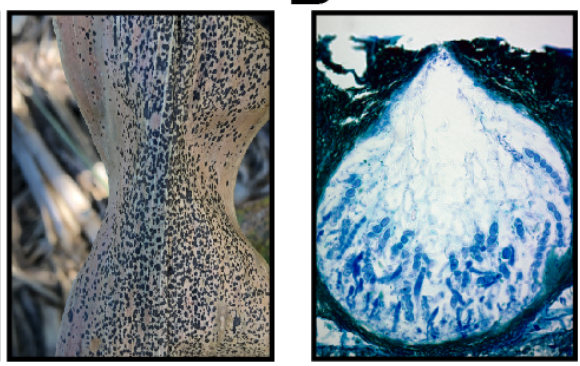

Susceptible

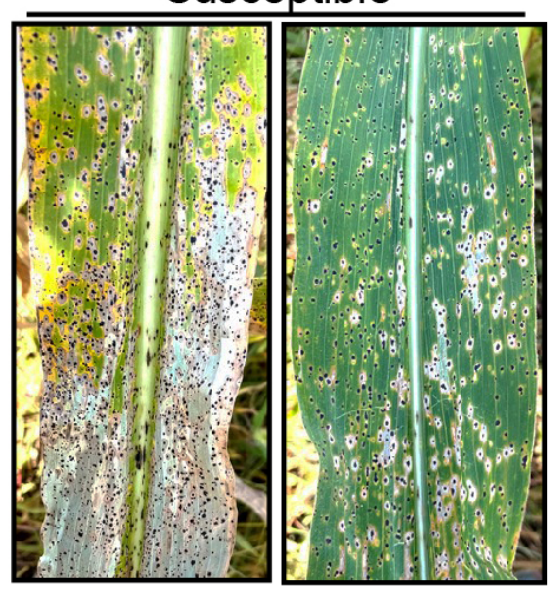

Figure 2 
A

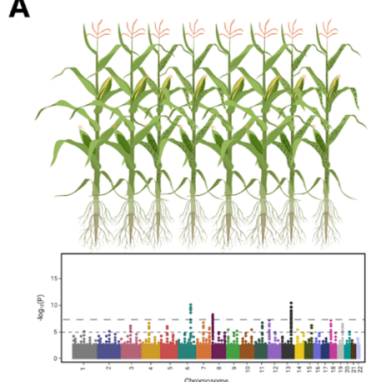

C

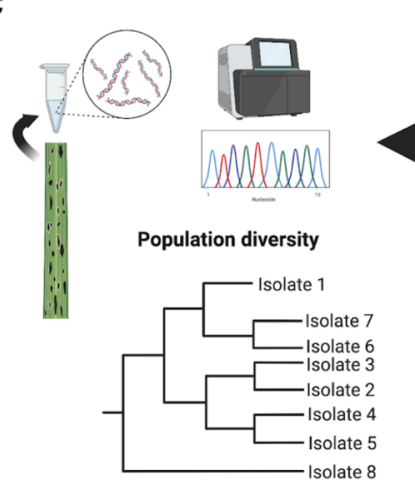

B

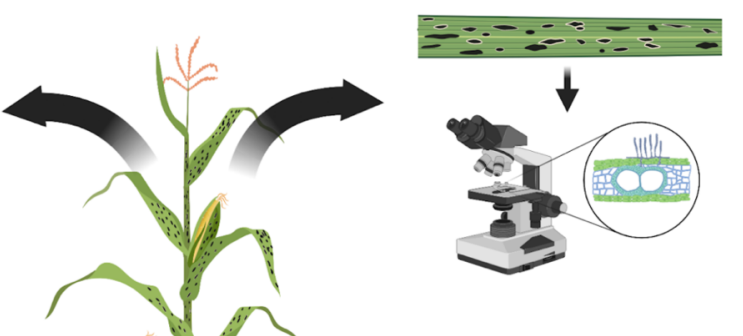

D

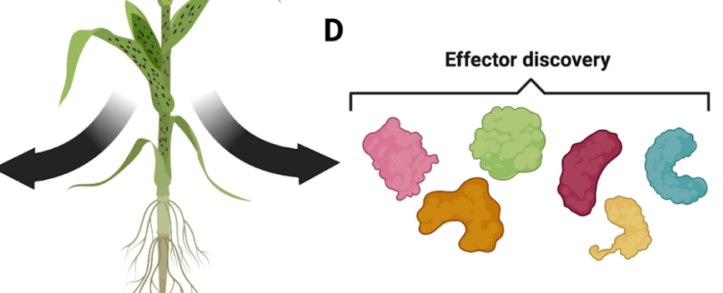

Subcellular localization
Effector-host protein
interactions 